\title{
Further evidence localising the gene for Hunter's syndrome to the distal region of the $\mathrm{X}$ chromosome long arm
}

\author{
SELWYN H ROBERTS, MEENA UPADHYAYA, MANSOOR SARFARAZI, \\ AND PETER S HARPER \\ From the Institute of Medical Genetics, University Hospital of Wales, Cardiff CF4 4XW.
}

SUMmaRY Cytogenetic re-evaluation of a fibroblast cell line from a female Hunter's syndrome case with a balanced X;autosome translocation, which had previously been reported to have a breakpoint in Xq26 to Xq27, showed the breakpoint to be either between Xq27 and Xq28 or within Xq28. The normal X chromosome was preferentially inactivated, supporting the view that the translocation had disrupted the Hunter gene. The new localisation is now in full agreement with our previous linkage work and other published data. Results of further linkage studies using probes defining the loci $D X S 86, D X S 144, D X S 100, D X S 102, D X S 105, F 8 C$, and $D X S 134$ are also consistent with our original conclusion that the Hunter locus lies within the distal region of the $\mathrm{X}$ chromosome long arm.

We have previously reported genetic linkage between the Hunter's syndrome gene and DNA markers located distally on $\mathrm{Xq} .{ }^{1}$ The most likely order of these loci and their orientation, on the evidence of available data, appeared to be XcenDXS51-F9-Hunter-DXS15-DXS52-F8C-Xqter.

This order of markers around the Hunter locus is very similar to that established for the fragile $X$ locus. ${ }^{2-6}$ The linkage between the Hunter gene and distal Xq markers has been confirmed by Chase $e t$ $a l,{ }^{7}$ who also considered the Hunter locus to be distal to $F 9$. Since a number of workers had localised $F 9$ to $\mathrm{Xq27,},{ }^{8-10}$ it appeared probable that the Hunter gene was within the region Xq27 to Xqter. However, Schwartz et $a l^{11}$ have reported that the locus for F9 was retained in two sisters with a distal deletion at the $\mathrm{Xq} 26 / \mathrm{Xq} 27$ interface, suggesting a more proximal localisation of the F9 gene. In addition, the $X$;autosome translocation in a young girl with Hunter's disease reported by Mossman et $\mathbf{a l}^{12}$ was considered to have the breakpoint within $\mathrm{Xq} 26$ to Xq27. The authors argued that, by analogy to females suffering from Duchenne muscular dystrophy with translocations involving $\mathrm{Xp} 21$, the translocation breakpoint in the $\mathrm{X}$ chromosome had disrupted the gene for Hunter's syndrome, and they postulated that the normal $\mathrm{X}$ must be preferentially

Received for publication 24 October 1988.

Accepted for publication 21 November 1988. inactivated. These reports, in particular the latter case, appeared to contradict the linkage data. We have therefore re-examined this translocation in an attempt to define the breakpoint more accurately and to determine the replicative status of the normal $\mathrm{X}$ chromosome. We also present additional linkage data which support our original conclusions.

\section{Materials and methods}

CYTOGENETIC ANALYSIS

Cytogenetic investigations were undertaken on a fibroblast culture (supplied by Tønne Tønneson, Kennedy Instituttet, Glostrup) established from the patient with Hunter's syndrome and a balanced $\mathrm{X}$;autosome translocation reported by Mossman et al. ${ }^{12}$ Chromosome preparations were obtained using conventional techniques except that the hypotonic solution was $0.022 \mathrm{~mol} / \mathrm{KC} 1$ and exposure to colcemid was restricted to 30 minutes in order to obtain chromosomes suitable for high resolution studies. GTG banding was accomplished using a modification of the method of Seabright ${ }^{13}$ and RBG banding was by a method adapted from that of Perry and Wolff, ${ }^{14}$ which included the addition of BrdU for the last five hours of culture to release a methotrexate block, the exposure of the chromosome preparations to UV light, treatment with $2 \times$ SSC at $60^{\circ} \mathrm{C}$ for 10 minutes, and staining with $10 \%$ Giemsa. 
DNA AND LINKAGE ANALYSIS

Eleven families showing unequivocal $X$ linked inheritance of Hunter's syndrome in at least two generations were studied. ${ }^{1}$

Total genomic DNA was extracted from venous blood samples and digested with the appropriate restriction endonucleases using standard procedures. The DNA fragments were separated according to molecular weight by agarose gel electrophoresis and hybridised, after Southern blotting onto Hybond-N (Amersham), to radiolabelled probes. The probes St1, c11, pX45h, cX38.1, cX55.7, F8A, and cpX67, which respectively define the loci $D X S 86, D X S 144, D X S 100, D X S 102$, $D X S 105, F 8 C$, and $D X S 134$ in the distal Xq region, ${ }^{3}$ were used. The physical localisation of these probes and the allele frequencies are shown in table 1 . With the exception of F8A, these probes were not used in the original study. ${ }^{1}$ In the present study, the heterozygosity for F8A, which we had previously used to detect the $B c l$ lI polymorphism, was increased by the additional use of a polymorphism for the $B g l$ I restriction endonuclease. Analysis of linkage between the Hunter locus and these probes was carried out using the LIPED and LINKAGE computer program packages. ${ }^{15} 16$

\section{Results}

\section{CYTOGENETICS}

Results of both GTG and RBG banding techniques were consistent with the breakpoint on the $X$ chromosome being at $\mathrm{Xq} 28$ or at the $\mathrm{Xq} 27 / \mathrm{Xq} 28$ interface, rather than between $\mathrm{Xq} 26$ and $\mathrm{Xq} 27$ as previously suggested ${ }^{12}$ (figs 1 and 2). In particular, RBG banding showed that band Xq27, which is later replicating and more distinctive than any band in the distal $5 q$ region, had remained on the derived $X$ chromosome. The balanced reciprocal translocation was thus interpreted as $t(X ; 5)(q 28 ; q 33)$. The normal $\mathrm{X}$ chromosome was late replicating in each of 20 cells examined.

TABLE 1 The physical localisation and the allele frequencies of the marker loci in the present study.

\begin{tabular}{lllll}
\hline Probe & Locus & $\begin{array}{l}\text { Physical } \\
\text { localisation }\end{array}$ & Enzyme & $\begin{array}{l}\text { Allele } \\
\text { frequencies }\end{array}$ \\
\hline St1 & DXS86 & Xq26 & BgIII & $0 \cdot 72,0 \cdot 28$ \\
c11 & DXS144 & Xq26 & TaqI & $0 \cdot 50,0 \cdot 50$ \\
pX45h & DXS100 & Xq26 & TaqI & $0 \cdot 81,0 \cdot 19$ \\
cX38.1 & DXS102 & Xq26.2-q27.1 & TaqI & $0 \cdot 94,0 \cdot 06$ \\
& & X & MspI & $0 \cdot 86,0 \cdot 14$ \\
cX55.7 & DXS105 & Xq27 & EcoRI & $0 \cdot 92,0 \cdot 08$ \\
F8A & F8C & Xq28 & BclI & $0 \cdot 94,0 \cdot 06$ \\
& & & BglI & $0 \cdot 79,0 \cdot 21$ \\
cpX67 & DXS134 & Xq28 & MspI & $0 \cdot 72,0 \cdot 28$ \\
\hline
\end{tabular}

LINKAGE ANALYSIS

Table 2 shows the linkage analysis of the Hunter locus and the distal $\mathrm{Xq}$ markers used in this study. For the probes cX38.1 and F8A the combined haplotype data were used to calculate lod scores. Lod scores greater than 2 were obtained for $D X S 86$ $(Z \max =2.03$ at $\theta=0.19)$ and for $F 8 C(Z \max =2.25$ at $\theta=0 \cdot 17)$, and are indicative, particularly when taken in conjunction with our previous data, ${ }^{1}$ of linkage between the Hunter locus and markers in distal Xq. Lower lod scores may well reflect the uninformativeness of the probes rather than the lack of linkage, given the physical localisation of these probes. ${ }^{3}$ The improved maximum lod score of 2.25 for $F 8 C$ compared with 1.5 in our previous study ${ }^{1}$ appears to support this view.

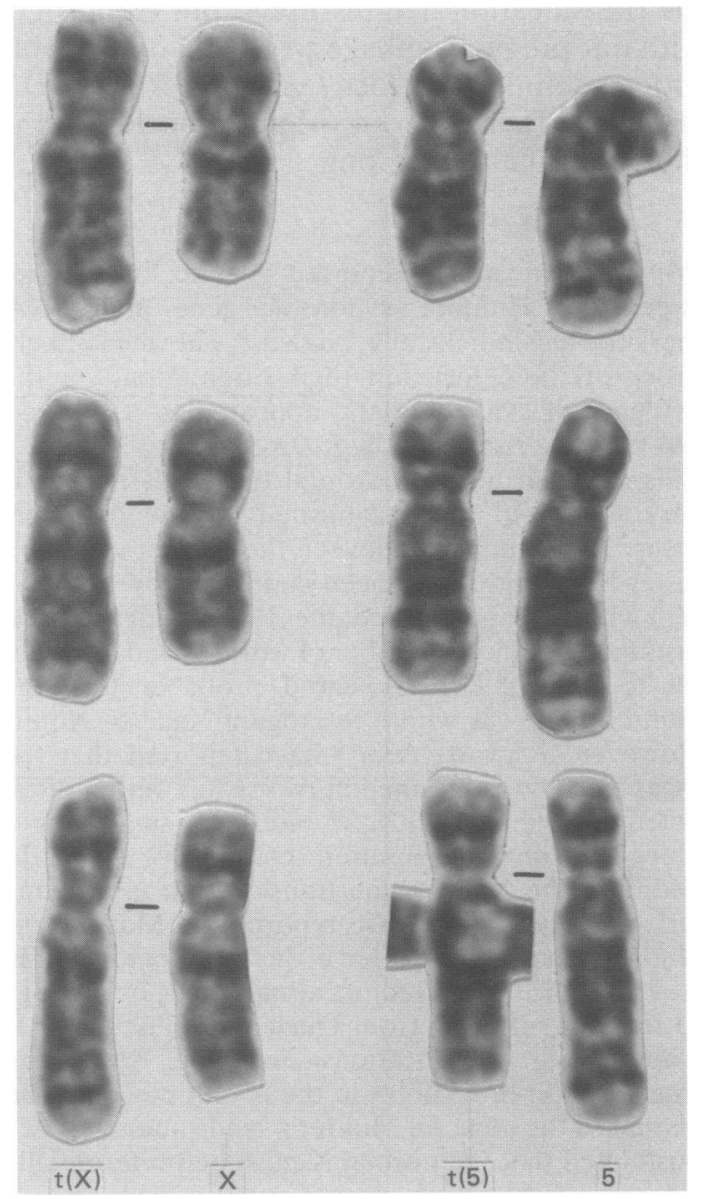

FIG 1 GTG banding showing the $t(X ; 5)(q 28 ; q 33)$ with normal homologous chromosomes from three cells. 


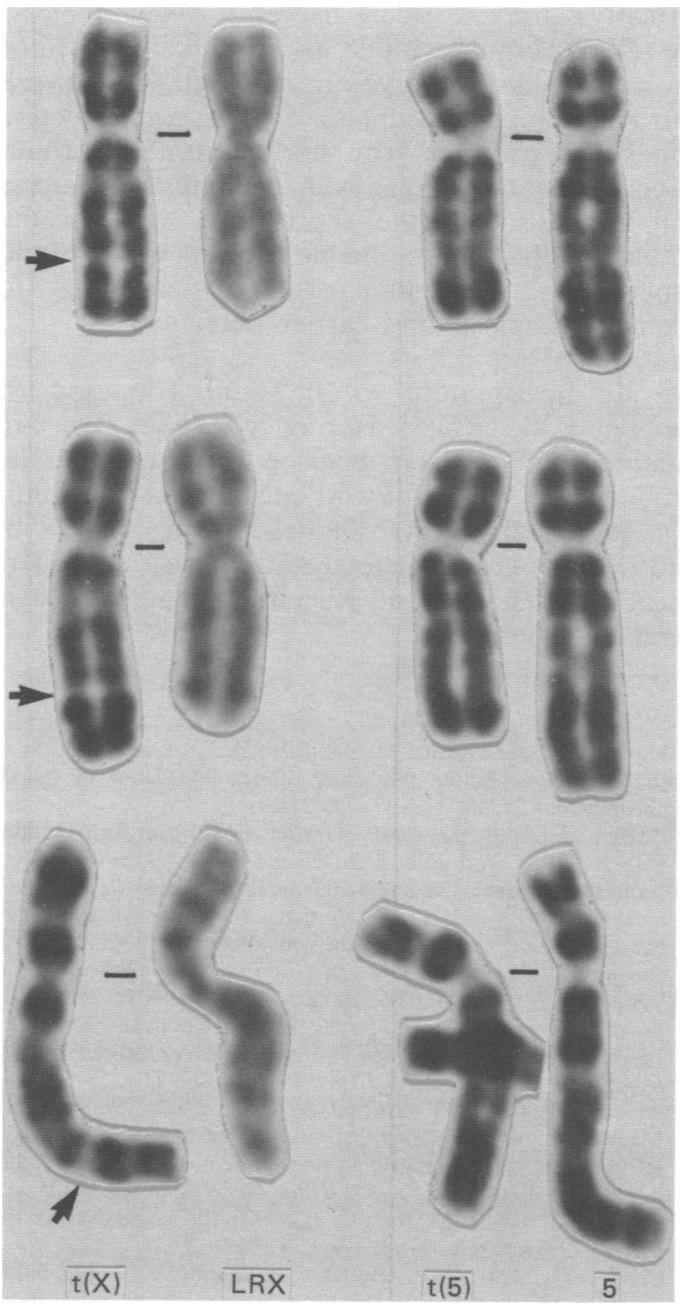

FIG $2 R B G$ banding showing the $t(X ; 5)(q 28 ; q 33)$ with normal homologous chromosomes from three cells. The late replicating Xq27 band is visible (arrows) in the translocation $X$. The normal $X$ is late replicating in all cells.
TABLE 3 The number of recombinants between Hunter's syndrome and each RFLP studied in phase known and phase unknown informative meioses.

\begin{tabular}{lll}
\hline & \multicolumn{2}{l}{ Recombinants/meioses } \\
\cline { 2 - 3 } & $\begin{array}{l}\text { Phase } \\
\text { unknown }\end{array}$ & $\begin{array}{l}\text { Phase } \\
\text { known }\end{array}$ \\
\hline St1 & $3 / 16$ & $3 / 16$ \\
c11 & $0 / 5$ & $3 / 12$ \\
pX45h & $2 / 15$ & $3 / 6$ \\
cX38.1 & & $1 \mathrm{R}$ \\
TaqI & $3 / 8$ & $3 \mathrm{NR}$ \\
MspI & $1 / 3$ & $1 \mathrm{R}$ \\
cX55.7 & & - \\
TaqI & $1 / 4$ & $2 / 5$ \\
EcoRI & - & $1 / 4$ \\
F8A & $1 / 11$ & - \\
BclI & $3 / 14$ & \\
BglI & $1 / 7$ & \\
cpX67 & &
\end{tabular}

Table 3 shows the number of recombinants in phase unknown and phase known meioses with each RFLP used in this study. DXS105 showed two recombinants with the Hunter locus in five informative meioses. The phase of one of these was unknown, but the other involved an affected male in whom the phase of the Hunter locus was known (families 9 and 8 respectively $^{1}$ ). In the latter case, recombination was also observed between the Hunter locus and the more proximal marker $D X S 86$, but not with the distal marker $F 8 C$. Thus the Hunter locus appears to be distal to DXS105.

\section{Discussion}

The further linkage data support our original localisation $^{1}$ of the Hunter gene to the distal region of the $\mathrm{X}$ chromosome long arm. The Hunter locus appears to be bracketed distally by a tightly linked cluster of markers, including $F 8 C$ and $D X S 15$, that have been localised to $\mathrm{Xq} 28,{ }^{3}$ and proximally by a cluster of markers which include DXS86 and F9C. DXS86 has been localised to Xq26-q27, ${ }^{17} 18$

TABLE 2 Analysis of linkage between Hunter's syndrome and seven distal Xq markers.

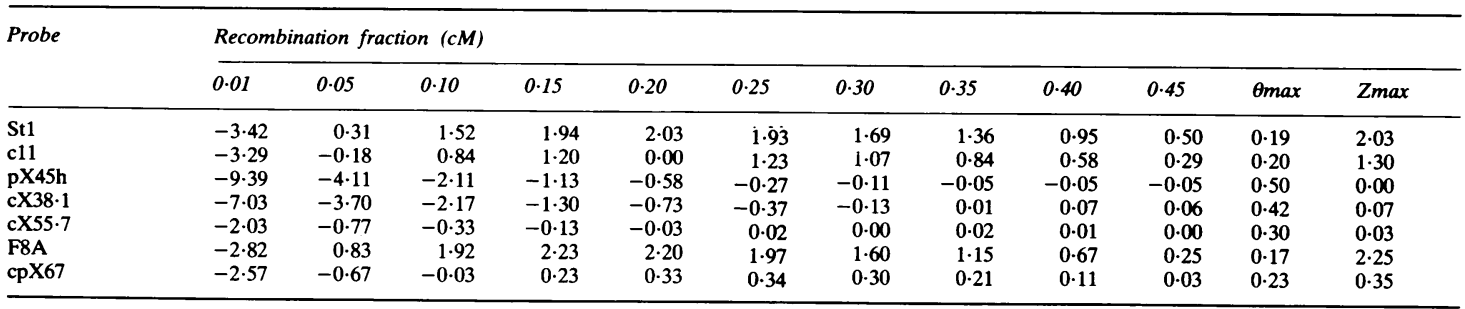


while several groups of workers ${ }^{8-10}$ have localised $F 9 C$ to $\mathrm{Xq} 27$, although $F 9 C$ was apparently retained on the abnormal $\mathrm{X}$ of two sisters with a distal deletion of the $X$, which was considered to include $\mathrm{Xq} 27$ and Xq28. ${ }^{11}$ The combined data of our present and previous studies ${ }^{1}$ show maximum lod scores of 1.24 at $\theta=0.25$ and 2.03 at $\theta=0.19$ for the linkage between the Hunter locus and the proximal markers $F 9 C$ and $D X S 86$ respectively, and maximum lod scores of 2.25 at $\theta=0.17$ and 1.6 at $\theta=0.2$ for linkage between the Hunter locus and the distal markers $F 8 C$ and $D X S 15$ respectively. This is in broad agreement with the work of Chase et al ${ }^{7}$ who found that the maximum lod score for linkage between the Hunter locus and $F 9 C$ was 0.42 at $\theta=0.25$, while that for $D X S 15$ was 3.01 at $\theta=0 \cdot 10$.

These data are very similar to the linkage relationship recently established for the fragile $X$ syndrome lesion by several research groups ${ }^{2-6}$ and strongly suggests that the Hunter locus is close to the fragile $\mathrm{X}$ site, which has been localised to $\mathrm{Xq} 27.3 .{ }^{19}$ The marker $D X S 105$ has been shown to be on the centromeric side of the fragile $\mathrm{X}$ locus, ${ }^{3}$ to which, at least in one large family, it is closely linked with a maximum lod score of 5 at $\theta=0 \cdot 04 .^{4}$ In the present study, DXS105 showed two recombinants in five informative meioses with the Hunter locus. Furthermore, the data showed that the Hunter locus is distal to DXS105. This suggests that the Hunter locus is also distal to the fragile $\mathrm{X}$ site, although heterogeneity of recombination between DXS105 and the fragile $X$ site, with some families showing loose linkage, ${ }^{5}$ could also account for the recombinants in our study.

Re-evaluation of the translocation in a girl with Hunter's syndrome reported by Mossman et al, ${ }^{12}$ however, supports the more distal localisation, since the breakpoint is most probably at the interface of $\mathrm{Xq} 27$ and $\mathrm{Xq} 28$ or within $\mathrm{Xq} 28$. This assignment is based on the use of higher resolution GTG banding than was available in the above study ${ }^{12}$ and, in particular, on the use of RBG banding which allowed Xq27 to be distinguished from the earlier replicating chromosome 5 distal long arm bands. These techniques enabled a more accurate determination of the breakpoint, which is distal to that given in the original publication. ${ }^{12}$ There remains thus no disagreement between the linkage and cytogenetic data. Furthermore, the normal $\mathrm{X}$ in this patient, in being consistently late replicating, appears to have been preferentially inactivated. This is consistent with the hypothesis of Mossman et $a^{12}$ that the Hunter gene has been disrupted at the site of the translocation breakpoint.

It is clear, though, that to localise the Hunter gene unequivocally further family studies or more in- formative probes will be necessary. Nevertheless, the $t(X ; 5)$ Hunter cell line may eventually prove to be a valuable resource in the isolation of the iduronate sulphate sulphatase gene, which determines this syndrome. The more accurate determination of the breakpoint will facilitate this process and may also, in the short term, help in the identification of more reliable markers which would expedite the application of DNA technology to prenatal diagnosis and carrier detection.

We are most grateful to Dr Tønne Tønneson for supplying the $t(X ; 5)$ Hunter cell line. We are indebted to $\mathrm{Dr}$ Peter Pearson for providing the probes cX55.7, cX38.1 and cpX67, Dr Jean-Louis Mandel for cll and St1, Dr Brad White for pX45h, and Dr Jane Gitschier for F8A. We also thank Drs Nicholas S Thomas and Richard Wheater for their invaluable help.

\section{References}

1 Upadhyaya M, Sarfarazi M, Bamforth JS, et al. Localisation of the gene for Hunter syndrome on the long arm of the $\mathrm{X}$ chromosome. Hum Genet 1986;74:391-8.

2 Buchanan JA, Buckton KE, Gosden CM, et al. Ten families with fragile $X$ syndrome: linkage relationships with four DNA probes from distal Xq. Hum Genet 1987;76:165-72.

3 Davies KE, Mandel JL, Weissenbach J, Fellous M. Report of the committee on the genetic constitution of the $X$ and $Y$ chromosomes. HGM9. Cytogenet Cell Genet 1987;46:277-315.

4 Veenema H, Carpenter NJ, Bakker E, Hofker MH, Millington Ward A, Pearson PL. The fragile $X$ syndrome in a large family. III. Investigations on linkage of flanking DNA markers with the fragile site Xq27. J Med Genet 1987;24:413-21.

5 Arveiler B, Oberlé I, Vincent A, Hofker MH, Pearson PL, Mandel JL. Genetic mapping of the Xq27-q28 region: new RFLP markers useful for diagnostic applications in fragile- $X$ and hemophilia-B families. Am J Hum Genet 1988;42:380-9.

6 Brown WT, Gross A, Chan C, et al. Multilocus analysis of the fragile X syndrome. Hum Genet 1988;78:201-5.

7 Chase DS, Morris AH, Ballabio A, Pepper S, Giannelli F, Adinolfi M. Genetics of Hunter syndrome: carrier detection, new mutations, segregation and linkage analysis. Ann Hum Genet 1986;50:349-60.

8 Buckle V, Craig IW, Hunter D, Edwards JH. Fine assignment of the coagulation factor IX gene. HGM8. Cytogenet Cell Genet 1985;40:593-4.

9 Mattei MG, Baeteman MA, Heilig R, et al. Localization by in situ hybridization of the coagulation factor IX gene and of two polymorphic DNA probes with respect to the fragile $\mathrm{X}$ site. Hum Genet 1985;69:327-31.

10 Purrello M, Alhadeff B, Esposito D, et al. The human genes for hemophilia $A$ and hemophilia $B$ flank the $X$ chromosome fragile site at Xq27.3. EMBO J 1985;4:725-9.

11 Schwartz C, Fitch N, Phelan MC, Richer CL, Stevenson R. Two sisters with a distal deletion at the $\mathrm{Xq} 26 / \mathrm{Xq} 27$ interface: DNA studies indicate that the gene locus for factor IX is present. Hum Genet 1987;76:54-7.

12 Mossman J, Blunt S, Stephens R, Jones EE, Pembrey M. Hunter's disease in a girl: association with $\mathrm{X}: 5$ chromosomal translocation disrupting the Hunter gene. Arch Dis Child 1983;58:911-5.

13 Seabright M. A rapid banding technique for human chromosomes. Lancet 1971;ii:971-2. 
${ }^{14}$ Perry P, Wolff S. New giemsa method for the differential staining of sister chromatids. Nature 1974;251:156-8.

$15 \mathrm{Ott} \mathrm{J}$. Estimation of the recombination fraction in human linkage studies. Am J Hum Genet 1974;26:588-97.

${ }^{16}$ Lathrop GM, Lalouel JM, Julier C, Ott J. Strategies for multilocus linkage analysis in humans. Proc Natl Acad Sci USA 1984;81:3443-6.

17 Oberlé I, Camerino G, Kloepfer C, et al. Characterization of a set of X-linked sequences and of a panel of somatic cell hybrids useful for the regional mapping of the human $\mathrm{X}$ chromosome. Hum Genet 1986;72:43-9.

18 Oberlé I, Camerino G, Wrogemann K, et al. Multipoint genetic mapping of the Xq26-q28 region in families with fragile $\mathrm{X}$ mental retardation and in normal families reveals tight linkage of markers in q26-q27. Hum Genet 1987;77:60-5.

19 Krawczun MS, Jenkins EC, Brown WT. Analysis of the fragile$\mathrm{X}$ chromosome: localization and detection of the fragile site in high resolution preparations. Hum Genet 1985;69:209-11.

Correspondence to $\mathrm{Mr} \mathrm{S} \mathrm{H}$ Roberts, Institute of Medical Genetics, University Hospital of Wales, Heath Park, Cardiff CF4 4XW. 